The aldolas 3 concentration in sarcoplasm from foetal skeletal muscle is low, like that of adult heart muscle, although the enzymic activity rises as the foetus develops. The general conclusion of this comparison is that at least for the components moving towards the cathode foetal-muscle sarcoplasm is more comparable with that of adult heart muscle than that of white skeletal muscle. The sarcoplasm of red skeletal muscle appears to be intermediate between these two types. The high concentration of aldolase in the adult-skeletalmuscle sarcoplasm might be expected in view of the well-developed ability of this tissue to function anaerobically. These facts together with our findings suggest that after birth aldolase and other proteins of a high isoelectric point increase rapidly in amount in response to the increased activity of the skeletal muscle.

\section{SUMMARY}

1. Rabbit skeletal muscle has been fractionated by chromatography on diethylaminoethylcellulose at $\mathrm{pH} \mathbf{7 \cdot 6}$ and $\mathbf{9 \cdot 3}$.

2. On starch-gel electrophoresis of adult-rabbitskeletal muscle at least 15 migrating bands have been recognized and some of them identified with known proteins.

3. The more positively charged protein components which are readily eluted from diethylaminoethylcellulose are relatively much decreased in sarcoplasm isolated from foetal-rabbit skeletal muscle and from adult heart muscle compared with the amounts present in the corresponding fraction from adult skeletal muscle.

4. The level of aldolase activity in foetalskeletal-muscle sarcoplasm is comparable with that in adult-heart-muscle sarcoplasm but much lower than that found in adult-rabbit-skeletal muscle sarcoplasm.

This work was done during the tenure of a Guinness Research Scholarship by one of us (D.J.H.). We are indebted to the National Science Foundation for a grant (NSF-G 10938) which has defrayed in part the expenses incurred in this research. Our thanks are also due to Dr H. Feinberg and Dr D. G. Walker for help in the perfusion experiments.

\section{REFERENCES}

Bate-Smith, E. C. (1930). Proc. Roy. Soc. B, 105, 579. Chappell, J. B. \& Perry, S. V. (1954). Biochem. J. 57, 421. Coon, A. H. \& Kaplan, M. H. (1950). J. exp. Med. $91,1$. Crepax, P. (1952). Biochim. biophys. Acta, 9, 385.

Dubuisson, M. (1950). Biol. Rev. 25, 46.

Gitlin, D., Landing, B. H. \& Whipple, A. (1953). J. exp. Med. 97, 163.

Gitlin, D., Nakasato, D. \& Richardson, W. R. (1955). J. clin. Invest. 34, 935.

Hartshorne, D. J. \& Perry, S. V. (1961). Biochem. J. 80, 9 P.

Jacob, J. J. C. (1947). Biochem. J. 41, 83.

Marcaud, L. (1961). Abstr. 5th int. Congr. Biochem., Moscow, 201.

Mueller, H. \& Perry, S. V. (1961). Biochem. J. 80, 217.

Perry, S. V. (1956). Physiol. Rev. 36, 1.

Perry, S. V. (1960a). In Comparative Biochemistry, vol. 2, p. 245. Ed. by Florkin, M. \& Mason, H. S. New York: Academic Press Inc.

Perry, S. V. (1960b). Biochem. J. 74, 94.

Perry, S. V. \& Zydowo, M. (1959). Biochem. J. 71, 220.

Peterson, E. A. \& Sober, H. A. (1956). J. Amer. chem. Soc. 78, 751.

Rutter, W. J. (1961). In The Enzymes, vol. 5, p. 341. Ed. by Boyer, P. D., Lardy, H. \& Myrbäck, K. New York: Academic Press Inc.

Sibley, J. A. \& Lehninger, A. L. (1949). J. biol. Chem. 177, 859.

Smithies, O. (1955). Biochem. J. 61, 629.

Smithies, O. (1959). Advanc. Protein Chem. 16, 76.

Velick, S. F. (1949). J. phys. Colloid Chem. 53, 135.

Biochem. J. (1962) 85, 177

\title{
Protein Synthesis in Mitochondria
}

\section{THE CONTROLLED DISRUPTION AND SUBFRACTIONATION OF MITOCHONDRIA LABELLED IN VITRO WITH RADIOACTIVE VALINE*}

\author{
By D. B. ROODYN \\ National Institute for Medical Research, Mill Hill, London, N.W. 7
}

(Received 24 April 1962)

In previous publications from this Laboratory the conditions for incorporation of radioactive amino acids into the protein of isolated rat-liver mitochondria were examined (Reis, Coote \& Work,

* Part 2: Roodyn, Suttie \& Work (1962).
1959; Roodyn, Reis \& Work, $1961 a$ ) and negligible rates of incorporation in vitro were reported for the soluble proteins in the mitochondrial fraction, including catalase, malic dehydrogenase and cytochrome $c$ (Roodyn, Suttie \& Work, 1962). The 
chief site of incorporation was into material rich in RNA, phospholipid and succinoxidase that was not extracted by treatment with neutral detergents (Roodyn, 1961). In this paper the processes that occur during the fragmentation and extraction of mitochondria by the action of detergents have been studied and the distribution of radioactive protein in the various subfractions so obtained has been determined. By suitable variation in the conditions, it has been possible to obtain controlled disruption of the mitochondria and to demonstrate that the major site of incorporation in vitro is into insoluble lipoproteins probably associated with the mitochondrial membrane.

\section{METHODS}

\section{Preparation of mitochondrial subfractions}

Mitochondria. These were prepared from rat liver in 0.3 M-sucrose-2 mM-EDTA (disodium salt)-0.03 M-nicotinamide, as described by Roodyn et al. (1961 $a)$. They were subjected to subfractionation as follows.

Preliminary study of disruption with detergents (Figs. 1-4). Mitochondria were suspended in $0.3 \mathrm{M}$-sucrose and rapidly mixed with a suitable volume of $8 \%(v / v)$ detergent in $0.3 \mathrm{M}$-sucrose. The turbidity of the solution was immediately read in an EEL nephelometer, the instrument being set to 100 with a suspension of untreated mitochondria. In some experiments (Figs. 1 and 4) the degree of disruption was measured by immediately centrifuging the suspensions at $10000 \mathrm{~g}$ for $30 \mathrm{~min}$. and analysing the sediment for protein or total $\mathrm{N}$. To obtain satisfactory turbidity readings, the mitochondrial concentration used in these preliminary studies was less than that used in later experiments. Experiments in which turbidity was measured were carried out at room temperature. All others were carried out at $0^{\circ}$.

Isolation of RNA-lipoprotein complex (Fig. 5). Mitochondria suspended in $0.3 \mathrm{M}$-sucrose were treated with increasing amounts of detergent (Fig. 5). After $10 \mathrm{~min}$. at $0^{\circ}$ the suspension was centrifuged at $10000 \mathrm{~g}$ for $30 \mathrm{~min}$. The pellet (fraction A) was buff-coloured in the centre, but was surrounded by a rim of reddish brown translucent material. The turbid supernatant was centrifuged at $105000 \mathrm{~g}$ for $60 \mathrm{~min}$. and gave a reddish brown gel-like pellet (fraction B), which contained a small quantity of darker granules in the centre. The supernatant (fraction C) was optically clear and faint yellow in colour. For analysis, fractions A and B were resuspended in $0 \cdot 3 \mathrm{M}$-sucrose.

'Titration' with detergent (Figs. 6, 7 and 8). Portions (10 ml.) of solutions of Triton X 100 in $0.3 \mathrm{M}$-sucrose were added to Spinco centrifuge tubes (capacity $12 \mathrm{ml}$.). A portion $(2.0 \mathrm{ml}$.) of the mitochondrial suspension in $0.3 \mathrm{M}$ sucrose was blown into the detergent and the tubes were rapidly mixed and sealed. After the tubes had been centrifuged at $105000 \mathrm{~g}$ for $60 \mathrm{~min}$., the pellets were resuspended in $0.3 \mathrm{M}$-sucrose for analysis.

Preparation and subfractionation of crude RNA-lipoprotein complex (Tables 1, 2 and 5). The mitochondrial suspension, containing $150-200 \mathrm{mg}$. of protein, was incubated in $30 \mathrm{ml}$. of radioactive incubation medium, brought to $0^{\circ}$ and $1.0 \mathrm{ml}$. of carrier valine $(10 \mathrm{mg} . / \mathrm{ml}$.) was added. The suspension was made up to $50.0 \mathrm{ml}$. with $0.3 \mathrm{M}$-sucrose, $2.0 \mathrm{ml}$. of $8 \%(\mathrm{v} / \mathrm{v})$ Triton X 100 in $0.3 \mathrm{M}$-sucrose added, and the suspension was immediately centrifuged at $105000 \mathrm{~g}$ for $60 \mathrm{~min}$. The resulting pellet was resuspended in either $50 \mathrm{ml}$. of $0.5 \%(\mathrm{v} / \mathrm{v})$ Triton X 100 in $0.3 \mathrm{M}$-sucrose or $50 \mathrm{ml}$. of $4.5 \%(\mathrm{v} / \mathrm{v})$ Triton $\mathrm{X} 100$ in $0.3 \mathrm{M}$-sucrose (Table 1 , Expts. 1 and 2) and left for $15 \mathrm{hr}$. at $0^{\circ}$. The material was centrifuged again at $105000 \mathrm{~g}$ for $60 \mathrm{~min}$. to give RNA-rich and lipid-rich components. Apart from chemical analysis, the sediment was not fractionated further. The supernatant was treated with $25 \mathrm{~g}$. of ammonium sulphate/ $100 \mathrm{ml}$. (Table 2). A flocculent precipitate appeared that was separated by filtration. The filtrate gave no further precipitate on the addition of more ammonium sulphate and was rejected. The precipitate was washed off the filter paper with $10 \mathrm{ml}$. of water and treated with $2 \mathrm{ml}$. of butan1-ol, added dropwise with constant stirring at $0^{\circ}$. The turbid solution was centrifuged at $3000 \mathrm{~g}$ for $15 \mathrm{~min}$. and a buffcoloured layer of protein appeared at the interface of the aqueous and butan-1-ol phases. It was carefully removed, resuspended in $10 \mathrm{ml}$. of water and treated with $2 \mathrm{ml}$. of butan-1-ol a second time. The floating buff layer again appeared after centrifuging. It was removed and resuspended in $0 \cdot 1 \mathrm{M}$-potassium phosphate, $\mathrm{pH} 7 \cdot 0$, in which it appeared to be completely insoluble.

The lipid-rich component, prepared as described in Table 1, Expt. 1, was subfractionated on calcium phosphate (Table 5) as follows: the fraction, containing 10$15 \mathrm{mg}$. of protein in $40 \mathrm{ml}$. of $0.3 \mathrm{M}$-sucrose- $0.5 \%$ Triton $\mathrm{X} 100$, was loaded directly on to a calcium phosphate column $(2.5 \mathrm{~cm} . \times 1.0 \mathrm{~cm}$.). The column was washed with

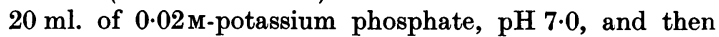
with $30 \mathrm{ml}$. of $1.0 \mathrm{M}$ buffer. Most of the coloured material on the column came off as a sharp band in the molar buffer and repeated washing with this buffer, or with $1 \cdot 0 \mathrm{M}$-potassium phosphate saturated with potassium chloride, failed to remove the remaining material attached to the column. The column was then suspended in 6-10 vol. of $1.0 \mathrm{M}$ sodium citrate, $\mathrm{pH} 5 \cdot 9$, and left at $0^{\circ}$ overnight. The faintly turbid solution was then centrifuged at $3000 \mathrm{~g}$ for $15 \mathrm{~min}$. A clear band of lipoprotein rose to the top of the tube. Some flocculent material was present in the underlying solution and there was a small precipitate at the bottom of the tube. The floating layer was removed carefully, suspended in $0 \cdot 2 \mathrm{M}$-potassium phosphate, $\mathrm{pH} 7 \cdot 0$, and dialysed for $15 \mathrm{hr}$. against several changes of this buffer. It was then centrifuged at $105000 \mathrm{~g}$ for $60 \mathrm{~min}$. and sedimented as a gel-like pellet.

The detergent-soluble proteins (Fig. 5, fraction C) were also submitted to this procedure (Table 6). The fraction containing 50-70 mg. of protein in $45 \mathrm{ml}$. of $0 \cdot 3 \mathrm{M}$-sucrose$0.2 \%$ Triton $\mathrm{X} 100$ was loaded, without prior dialysis, on to a calcium phosphate column $(8.0 \mathrm{~cm} . \times 1.3 \mathrm{~cm}$.) and treated exactly as described above. The fractionation appeared to be similar, except that a greater amount of protein passed through the column or was eluted with molar buffer. During elution with molar buffer an intense brownish yellow band with a sharp absorption peak at $410 \mathrm{~m} \mu$ came off the column. When the calcium phosphate, with its attached lipoprotein, was dissolved in sodium citrate and centrifuged, a thin layer of floating material was obtained but there was no sediment. The floating material sedimented as a gel-like pellet after dialysis and centrifuging at $105000 \mathrm{~g}$.

Preparation of 'structural protein' by method of Green, 
Tisdale, Criddle, Chen \& Bock (1961 b) (Table 3). Mitochondria containing $150 \mathrm{mg}$. of protein were incubated with $\left[{ }^{14} \mathrm{C}\right]$ valine. Carrier valine was added and the mitochondria were sedimented at $10000 \mathrm{~g}$ for $10 \mathrm{~min}$. They were resuspended in $20 \mathrm{ml}$. of detergent solution ( $0.25 \mathrm{M}$-sucrose$2 \%$ sodium deoxycholate-1\% sodium cholate- $0.75 \%$ sodium dodecyl sulphate). After $10 \mathrm{~min}$. at $0^{\circ}$, the lysed mitochondria were centrifuged at $105000 \mathrm{~g}$ for $60 \mathrm{~min}$. A greenish brown sediment was obtained. A trace of sodium dithionite was added to the supernatant and solid ammonium sulphate added slowly to give $12 \%$ saturation. The copious white precipitate was sedimented at $3000 \mathrm{~g}$ for $15 \mathrm{~min}$. and washed twice with $0.25 \mathrm{M}$-sucrose. It was suspended in $10 \mathrm{ml}$. of $20 \%$ saturated ammonium sulphate solution containing $20 \mathrm{mg}$. of sodium deoxycholate; $2.0 \mathrm{ml}$. of butan-1-ol was added dropwise and the material centrifuged at $3000 \mathrm{~g}$ for $10 \mathrm{~min}$. A layer of protein appeared at the interface of the butan-1-ol and aqueous phases. It was removed, washed with $0.25 \mathrm{M}$-sucrose, suspended in $6.0 \mathrm{ml}$. of $50 \%(\mathrm{v} / \mathrm{v})$ methanol and heated at $50^{\circ}$ for 30 sec. It was sedimented at $3000 \mathrm{~g}$ for $10 \mathrm{~min}$. and heated once more in $50 \%$ methanol at $50^{\circ}$ for 30 sec. The final sediment, which was a copious white precipitate, was taken as the 'structural protein'.

In the modification of the above method (Table 4) mitochondria containing $190 \mathrm{mg}$. of protein were disrupted with the cholate-deoxycholate-dodecyl sulphate mixture as described above. The sediment after $60 \mathrm{~min}$. at $105000 \mathrm{~g}$ was extracted a second time by suspending it in $10 \mathrm{ml}$. of the detergent solution and centrifuging at $105000 \mathrm{~g}$ for $60 \mathrm{~min}$. The supernatants from the two detergent treatments were then fractionated by the dropwise addition of increasing volumes of saturated ammonium sulphate. The precipitates were sedimented at $3000 \mathrm{~g}$ for $10 \mathrm{~min}$. and assayed for radioactive protein without further washing.

Incubation with radioactive amino acids. Mitochondria were incubated for $90 \mathrm{~min}$. at $30^{\circ}$ under oxygen with $0 \cdot 1 \mu \mathrm{C}$ of universally labelled $\mathrm{L}-\left[{ }^{14} \mathrm{C}\right]$ valine/ml. as described by Roodyn et al. (1961 $a$, 'medium B'). The media were not supplemented with antibiotics in these experiments. The radioactive valine and the methods used for the isolation and counting of the radioactive protein were as described by Roodyn et al. (1962).

Enzyme determinations. Malic dehydrogenase was estimated spectrophotometrically at $\mathrm{pH} \mathrm{9.9}$, as described by Roodyn et al. (1962). Succinoxidase was estimated manometrically by the method of Schneider \& Potter (1943). except that aluminium trichloride was omitted from the reaction mixture.

\section{Chemical estimations}

Acid-soluble material, RNA, phospholipid and protein were separated and estimated as described by Roodyn et al. $(1961 a)$. It was assumed that $1 \mathrm{mg}$. of phospholipid $P$ was derived from $25 \mathrm{mg}$. of phospholipid. In certain fractions, the presence of detergent interfered with the quantitative precipitation of the protein and nucleic acid. Trichloroacetic acid $(5 \%, \mathrm{w} / \mathrm{v})$ caused $0.2 \%$ Triton $\mathrm{X} 100$ to come out of solution and it then sedimented with the precipitated protein. It could then be readily removed by extraction with ethanol or acetone, but it is possible that when the ratio of detergent to protein was very high (cf. Tables 5 and 6, fraction C) protein was lost at this stage. The detergent is not thrown out of solution by $1.0 \mathrm{~N}$-perchloric acid.
However, preliminary experiments suggested that protein was not then fully precipitated. Attempts to remove the detergent by careful mixing with butan-1-ol, ether or chloroform were unsuccessful. Some improvement in the precipitation of protein from detergent solutions with $5 \%$ $(w / v)$ trichloroacetic acid was obtained by heating the suspension at $90^{\circ}$ for $30 \mathrm{~min}$. (this could not be used if RNA analyses were required). Because of these difficulties in obtaining quantitative precipitation, the results below are usually expressed as 'relative concentration' (i.e. value $/ \mathrm{mg}$. of protein divided by value $/ \mathrm{mg}$. of protein in intact mitochondria), rather than as a percentage of the total amount. (This can readily be obtained by multiplying 'relative concentration' by percentage of total protein.) In addition the percentage recoveries are often low because, apart from the experiments illustrated in Figs. 1-5, the assays on the mitochondrial subfractions were done after incubation of the mitochondria, whereas the value for intact mitochondria was obtained with fresh material. Breakdown of substances (e.g. RNA) during incubation would therefore give an apparently poor recovery. However, the poor recoveries of total protein and radioactivity in the more complex fractionations were undoubtedly due to failure to precipitate quantitatively from detergent solv ions.

\section{Materials}

Calcium phosphate was prepared as follows: $100 \mathrm{ml}$. of water was stirred with a magnetic stirrer and $250 \mathrm{ml}$. of $0.5 \mathrm{M}$-calcium chloride and $250 \mathrm{ml}$. of $0.5 \mathrm{M}$-disodium hydrogen phosphate were slowly dripped in, the phosphate being run in at twice the rate of the calcium chloride. The precipitated calcium phosphate was washed several times with water and then with $0 \cdot 02 \mathrm{M}$-sodium phosphate, $\mathrm{pH} 7 \cdot 0$. It was kept at $0^{\circ}$ and used within 5 days of preparation.

Radioactive valine was obtained from The Radiochemical Centre, Amersham, Bucks. The Triton detergents were kindly supplied by Charles Lennig and Co. Ltd., Bedford Row, London, W.C. 1. Sodium dodecyl sulphate was a recrystallized sample kindly provided by $\mathrm{Dr} H$. R. V. Arnstein.

\section{RESULTS}

\section{Study of factors influencing disruption of mitochondria by detergents}

Amongst several surface-active agents examined the neutral detergent Triton X100 (one of the alkylphenoxypolyethoxyethanol series produced by Rohm and Haas Co., Philadelphia, Pa., U.S.A.) was found to be most effective on a weight basis. Most of the experiments described below were with this detergent.

When Triton X 100 is added in sufficient concentration to a suspension of mitochondria, an immediate visual clearing occurs that is coincident with a marked fall in turbidity and with the release of protein and nucleic acid from the mitochondria, as shown by analyses on the $10000 \mathrm{~g}$ pellet (Fig. 1 ). If a sufficient concentration of detergent is used the fall in turbidity takes place in less than 5 sec., indicating an almost instantaneous lysis of the 
mitochondria. With lower concentrations of detergent, however, this immediate rapid fall is followed by a slower fall lasting 40-50 min. (Fig. 2). This slower fall also coincided with the release of protein and nucleic acid from the $10000 \mathrm{~g}$ pellet, and was

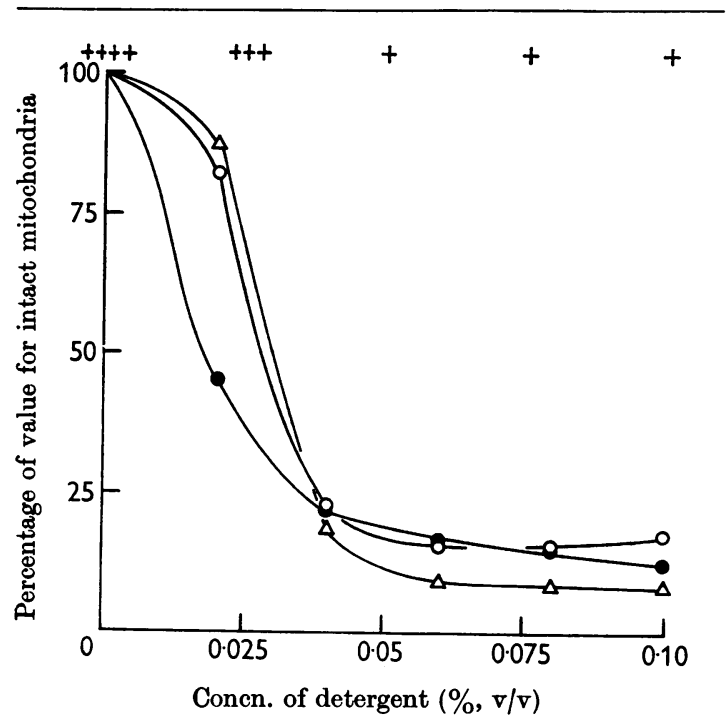

Fig. 1. Fall in turbidity, release of RNA and release of protein on disruption of mitochondria with detergent. -, Turbidity as measured in the EEL nephelometer; +, visual estimate of turbidity; $O$, RNA; $\triangle$, protein. Mitochondrial suspension in $0.3 \mathrm{M}$-sucrose, containing $0.6 \mathrm{mg}$. of protein $/ \mathrm{ml}$, was treated with increasing concentrations of Triton X100 and immediately centrifuged at $10000 \mathrm{~g}$ for 30 min. RNA and protein were determined in the sediment.

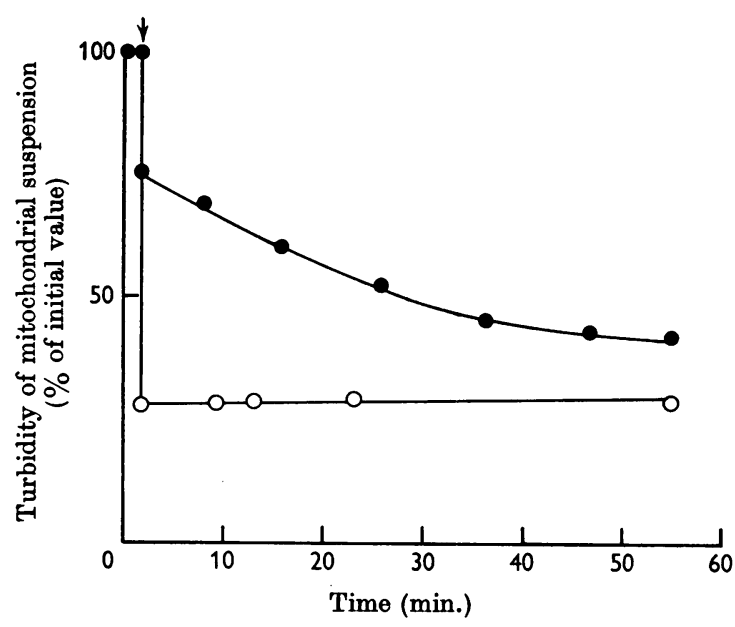

Fig. 2. Effect of time on fall in turbidity of mitochondrial suspension in the presence of detergent. Triton X 100 was added (at arrow) to a final concentration of $0.06 \%(O)$ or $0.02 \%(O)$ to a suspension of mitochondria in $0.3 \mathrm{M}$ sucrose containing $0.62 \mathrm{mg}$. of protein $/ \mathrm{ml}$. not simply due to swelling. For this reason, the time between addition of the detergent and separation of the mitochondrial subfractions was always kept to a minimum.

For a given concentration of detergent, the extent of disruption is also affected by the concentration of the mitochondrial suspension, the more dilute suspensions being more easily disrupted (Fig. 3). The degree of disruption is also affected by the length of the polyoxyethylene chain in the Triton detergent, Triton X 100 (with 9-10 ethylene oxide groups) and Triton $X 102$ (with 12-13 groups) being more effective, volume for volume, than Triton X 165 (16 groups) and Triton X 305 (30 groups) (Fig. 4). The long-chain detergents are also less effective on a molar basis. Thus $0.2 \%$ Triton $\mathrm{X} 165$, which contained $2 \cdot 22 \mu \mathrm{moles} / \mathrm{ml}$., was considerably less effective than $0.1 \%$ Triton $\times 100$, which contained only $1.54 \mu \mathrm{moles} / \mathrm{ml}$. To summarize, the extent of disruption of the mitochondria can be controlled by the detergent concentration, the mitochondrial concentration, the time the mitochondria are exposed to detergent and the length of the polyoxyethylene chain.

\section{Isolation of an RNA-lipoprotein complex from disrupted mitochondria}

The disrupted mitochondria were arbitrarily divided into three fractions: fraction $A$, sedimenting after $30 \mathrm{~min}$. at $10000 \mathrm{~g}$; fraction $\mathrm{B}$, sedimenting after $60 \mathrm{~min}$. at $105000 \mathrm{~g}$; fraction $\mathrm{C}$, the final supernatant. The distribution of phospholipid, RNA and protein was then determined in the

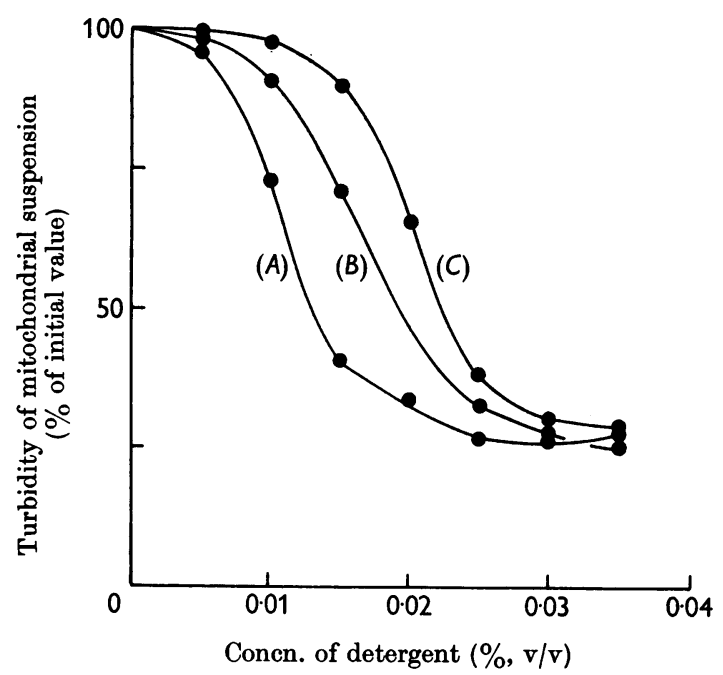

Fig. 3. Effect of mitochondrial concentration on disruption of mitochondria by detergent. Concn. of protein (mg./ml.): $(A) 0.21 ;(B) 0.42 ;(C) 0.63$. Mitochondria, in the concentrations shown, were treated with Triton $\mathrm{X} 100$. 
various fractions as the mitochondria were exposed to increasing concentrations of detergent (Fig. 5). As the detergent concentration is raised, protein, RNA and phospholipid disappear from the $10000 \mathrm{~g}$ sediment (fraction $\mathrm{A}$ ) in parallel with the disruption of the mitochondria and the fall in turbidity (cf. Fig. 1). Most of the protein appears in the final supernatant (fraction $\mathrm{C}$ ) and only about $20 \%$ is found in the $105000 \mathrm{~g}$ sediment (fraction B). However, this fraction takes a greater share of the phospholipid (about $30 \%$ ) and nearly half of the total RNA. As a result, it is richer in RNA and phospholipid than either the soluble material or intact mitochondria. More detailed properties of the three fractions are given in Roodyn et al. (1961 a, Table 5) and Roodyn et al. (1962, Table 3). (In the experiments published previously the mitochondrial suspension contained $\mathbf{4}-\mathbf{5} \mathrm{mg}$. of protein $/ \mathrm{ml}$. and the detergent concentration used was $0.2 \%, \mathrm{v} / \mathrm{v}$.)

Fraction $A$ (sediment after 30 min. at $10000 \mathrm{~g}$ ). As this fraction includes unbroken and swollen mitochondria, its precise composition varies greatly with the degree of disruption. In general, it is rich in RNA, phospholipid, succinoxidase and radioactive protein, and poor in malic dehydro-

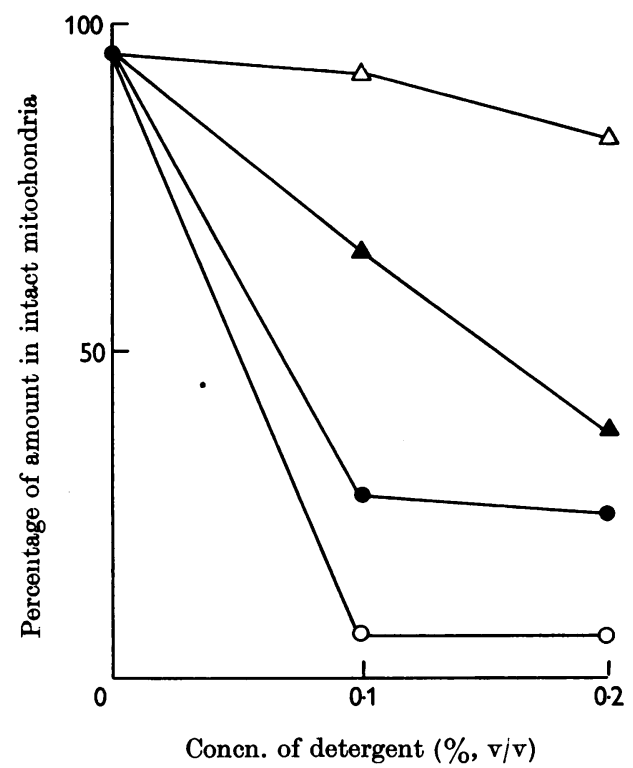

Fig. 4. Effect of chain length of detergent on the degree of disruption of mitochondria. Mitochondrial suspension containing $0.27 \mathrm{mg}$. of total $\mathrm{N} / \mathrm{ml}$. was treated for $10 \mathrm{~min}$. at $0^{\circ}$ with Triton $\mathrm{X} 100(0)$, Triton $\mathrm{X} 102$ (O), Triton $\mathrm{X} 165(\Delta)$ or Triton X305 $(\Delta)$ and then centrifuged at $10000 \mathrm{~g}$ for $10 \mathrm{~min}$. Total $\mathrm{N}$ was estimated in the sediments and expressed as a percentage of the total amount in the mitochondrial fraction. The $0 \cdot 1 \%$ solutions of the various detergents contained $1.54,1.36,1.11$ and $0.66 \mu$ moles respectively. genase if a high ratio of detergent to mitochondrial protein is used for lysis. Because it is then very similar in constitution to fraction $B$, in later work it has been combined with this fraction by omitting the centrifuging at $10000 \mathrm{~g}$ for $30 \mathrm{~min}$. (Fig. 6, Table 1).

Fraction $B$ (sediment after $60 \mathrm{~min}$. at $105000 \mathrm{~g}$ ' $R N A$-lipoprotein complex'). This is rich in RNA, phospholipid, succinoxidase and radioactive protein, and is poor in malic dehydrogenase. With the value for intact mitochondria taken as 1 , the relative concentrations of these components were $2 \cdot 07,1 \cdot 40,1 \cdot 14,2 \cdot 15$ and 0.56 respectively (Roodyn et al. $1961 a, 1962)$. The fraction appears as a reddish brown gel that is difficult to disperse in solution. In the visual spectroscope it has a diffuse band in the red and a faint band in the green. After reduction with a trace of sodium dithionite, clear bands appear at 605, 550 and $530 \mathrm{~m} \mu$. Treatment with up to $1.0 \mathrm{M}-\mathrm{NaCl}$ failed to extract any protein or nucleic acid. The precise yield and chemical composition of this fraction

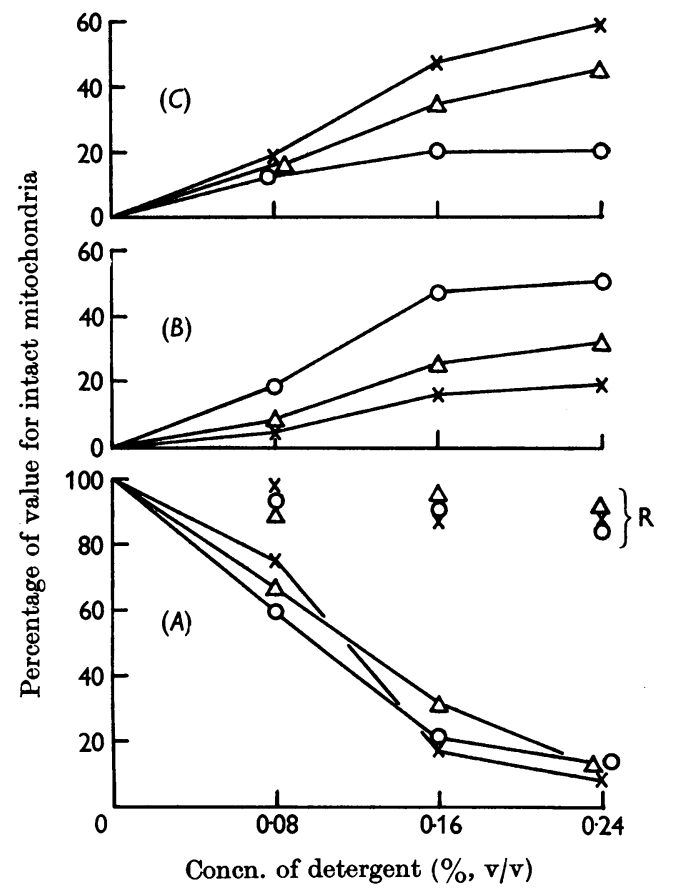

Fig. 5. Effect of detergent concentration on chemical composition of fractions derived from disrupted mitochondria. $O$, RNA; $\times$, protein; $\triangle$, phospholipid. R: recovery. Mitochondrial suspension in $0.3 \mathrm{M}$-sucrose, containing $5.05 \mathrm{mg}$. of protein $/ \mathrm{ml}$., was disrupted with Triton X100. The mitochondria contained $1.17 \mathrm{mg}$. of RNA and $20.9 \mathrm{mg}$. of phospholipid/100 mg. of protein. (A) $10000 \mathrm{~g}$ sediment; $(B) 105000 \mathrm{~g}$ sediment; (C) $105000 \mathrm{~g}$ supernatant. 
varies with the detergent concentration used, but it usually contains $10-20 \%$ of the total mitochondrial protein and has 3-5 mg. of RNA and $30-50 \mathrm{mg}$. of phospholipid/100 mg. of protein. From its properties, and by analogy with the results of other workers (see Discussion) there is little doubt that this fraction is derived mainly, if not entirely, from the mitochondrial membrane. For convenience, however, in later experiments fractions $A$ and $B$ have been combined and designated the 'crude RNA-lipoprotein complex'. Together they contain about two-thirds of the total radioactive protein.

Fraction $C$ (supernatant after 60 min. at $105000 \mathrm{~g}$ ). This fraction contains the bulk of the freely soluble material of the mitochondrion, including malic dehydrogenase. It has a relatively low concentration of phospholipid and RNA and has a low specific radioactivity. It has been examined in more detail elsewhere, together with the easily soluble protein fraction that is released during the incubation of the mitochondria (Roodyn et al. 1962).

\section{Sequential release of mitochondria components by 'titration' with detergent}

The above-mentioned fractionation had established that the bulk of the radioactive protein was in a fraction rich in phospholipid and RNA but it was not certain to which of these materials it was predominantly bound. The dissociation of radioactive protein from RNA, and its close relation with lipoprotein, was then demonstrated as follows. Mitochondria were exposed to increasing concentrations of Triton X100 and immediately sedimented at $105000 \mathrm{~g}$ for $60 \mathrm{~min}$. (Fig. 6). The sequential removal or inhibition of the various components is clearly demonstrated in this way, the order being: malic dehydrogenase, protein, succinoxidase, phospholipid, radioactive protein and finally RNA. The radioactive protein is found to be far more extractable than RNA and only slightly less extractable than succinoxidase and phospholipid. In this connexion it is interesting that the disappearance of succinoxidase activity from the pellet coincides with the removal of phospholipid, so that the ratio of succinoxidase to phospholipid remains constant throughout the experiment.

The difference in behaviour of the various components is shown strikingly if the results are expressed on the basis of 'relative concentration', i.e. value $/ \mathrm{mg}$. of protein divided by value/mg. of protein in intact mitochondria (Fig. 7). In Fig. 7, three stages are revealed during the 'titration' with detergent: $A$, the particles show no sign of damage, having identical concentrations of all the components as with the intact mitochondria; $B$, a pellet is obtained that is rich in phospholipid, RNA, succinoxidase and radioactive protein, but poor in malic dehydrogenase and protein; $C$, the pellet is rich in RNA but has only residual phospholipid, succinoxidase and radioactive protein. Fraction $B$ is similar in constitution to the RNAlipoprotein complex referred to above.

\section{Dissociation of crude RNA-lipoprotein complex into RNA-rich and lipid-rich components}

From the above results it would be expected that treatment of the material initially insoluble in detergent with more detergent should release phospholipid and radioactive protein, but not RNA. These expectations were confirmed in the experiments given in Table 1. The crude RNA-lipoprotein complex was treated with $50 \mathrm{ml}$. of $0.5 \%$ Triton X100 (Expt. 1) and a RNA-rich sediment and a lipid-rich extract were obtained. In Expt. 2 the detergent concentration was raised to $4.5 \%$ (v/v). As a result the extracted material had a very high lipid:protein ratio, whereas the residual material was enriched in RNA sevenfold compared with the original mitochondria, and had a very

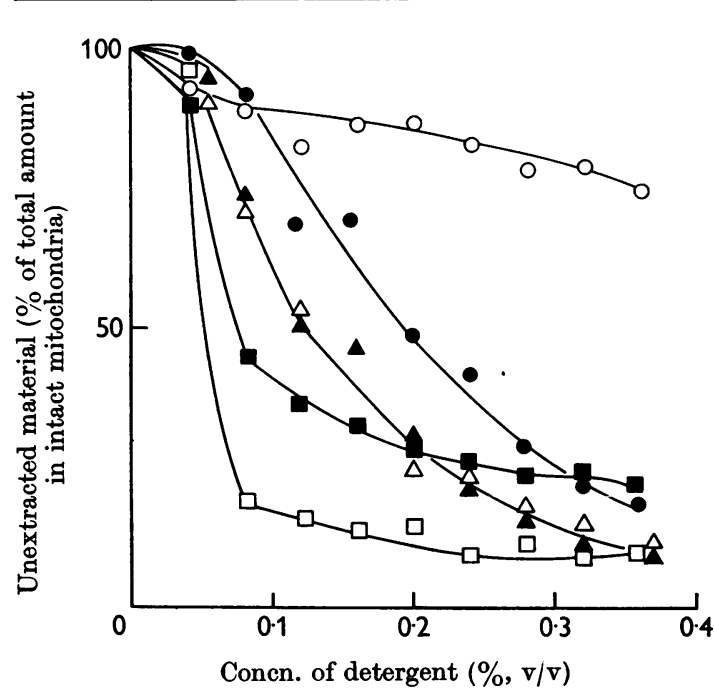

Fig. 6. Sequential extraction of components from mitochondria by treatment with increasing concentrations of detergent. $\mathrm{O}, \mathrm{RNA}$; $\square$, protein; $\bigcirc$, radioactivity in protein; $\triangle$, phospholipid; $\Delta$, succinoxidase; $\square$, malic dehydrogenase. Mitochondrial suspension, containing $1.48 \mathrm{mg}$. of protein $/ \mathrm{ml}$., was disrupted with Triton X 100 and immediately centrifuged for $60 \mathrm{~min}$. at $105000 \mathrm{~g}$. The pellet was analysed. The mitochondria contained $1.27 \mathrm{mg}$. of RNA and $27 \cdot 2 \mathrm{mg}$. of phospholipid/100 mg. of protein. Their succinoxidase activity was $470 \mu \mathrm{l} . / \mathrm{hr} . / \mathrm{mg}$. of protein and the malic-dehydrogenase activity 3.95 units $/ \mathrm{mg}$. of protein. The protein had a radioactivity of $37 \cdot 2 \mu \mu \mathrm{c} / \mathrm{mg}$. 
low lipid content. The protein in it was considerably less radioactive than the protein in the extracted lipid-rich component.

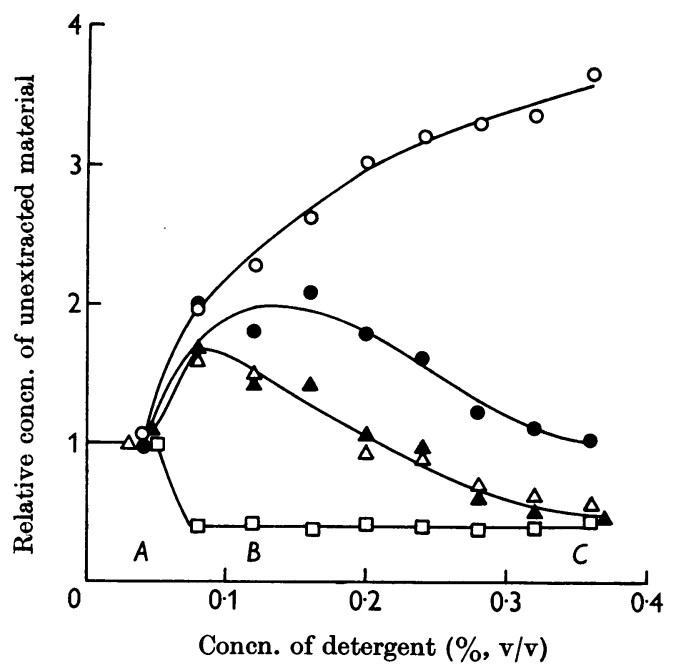

Fig. 7. Change in relative concentration of components of mitochondria during sequential extraction with detergent. $O$, RNA; O, radioactivity in protein; $\triangle$, phospholipid; $\square$, malic dehydrogenase; $\boldsymbol{\Delta}$, succinoxidase. Relative concentration is value $/ \mathrm{mg}$. of protein divided by value $/ \mathrm{mg}$. of protein for intact mitochondria (intact mitochondria = 1). Values for mitochondria are given in Fig. 6. See text for description of fractions $A, B$ and $C$.
Lipoproteins present in lipid-rich component

Relation to 'structural protein' of Green et al. $(1961 \mathrm{~b})$. The crude lipoprotein extracted by the second detergent treatment was precipitated, together with some detergent, by the addition of $25 \mathrm{~g}$. of ammonium sulphate $/ 100 \mathrm{ml}$. of solution (Table 2). The material obtained was about four times as radioactive as the total mitochondrial protein and had the ratio of RNA :phospholipid: protein $0 \cdot 7: 55 \cdot 0: 44 \cdot 3$. When it was treated with butan-1-ol a precipitate was obtained that was insoluble in $0 \cdot 1 \mathrm{~m}$-potassium phosphate, $\mathrm{pH} \mathrm{7.0.} \mathrm{It}$ dissolved slowly in $0.1 \mathrm{~N}$-sodium hydroxide and only partially in $8 \mathrm{~m}$-urea. It could be dissolved in $8 \mathrm{M}$-urea-0.1\% sodium dodecyl sulphate, however, and, in this solvent, had an absorption maximum at $277 \mathrm{~m} \mu$ and a minimum at $247 \mathrm{~m} \mu$. There was no evidence of a peak at $260 \mathrm{~m} \mu$ and the ratio $E_{260} / E_{280}$ was $\mathbf{0} \cdot 82$, indicating a low nucleic acid content. There was negligible absorption at $410 \mathrm{~m} \mu$ or between 520 and $605 \mathrm{~m} \mu$ either before or after treatment with sodium dithionite, which suggested that haem derivatives were absent. The material therefore closely resembled the 'structural protein, S.P.' described by Green et al. (1961b) for ox-heart mitochondria.

The procedure of these workers was therefore applied to rat-liver mitochondria (Table 3) and a protein was obtained (fraction $J$ ) that had similar solubility properties to that obtained from oxheart mitochondria by Green and co-workers. It

Table 1. Dissociation of crude ribonucleic acid-lipoprotein complex into ribonucleic acid-rich and lipid-rich fractions, by further treatment with detergent

Expt. 1: mean of five fractionations. Mitochondrial protein had a final radioactivity of $41.9 \mu \mu \mathrm{c} / \mathrm{mg}$. and had $2.35 \mathrm{mg}$. of RNA and $26.6 \mathrm{mg}$. of phospholipid/100 mg. of protein. Crude RNA-lipoprotein complex containing $45 \mathrm{mg}$. of protein was treated overnight at $0^{\circ}$ with $50 \mathrm{ml}$. of $0.5 \%$ Triton X 100. Expt. 2: crude RNA-lipoprotein complex, prepared as in Expt. no. 1 and containing $29 \mathrm{mg}$. of protein, was treated at $0^{\circ}$ overnight with $50 \mathrm{ml}$. of $4.5 \%(v / v)$ Triton X 100 .

Expt. no. 1

(1) Total mitochondrial protein

(2) Treat (1) with detergent: $60 \mathrm{~min}$. at $105000 \mathrm{~g}$ :

Supernatant

Sediment

(3) Sediment from (2) (RNA-lipoprotein complex) treated with detergent: $60 \mathrm{~min}$. at $105000 \mathrm{~g}$ :

Sediment
Supernatant

(1) Total mitochondrial protein

(2) RNA-lipoprotein complex from (1)

(3) Treat (2) with detergent: $60 \mathrm{~min}$. at $105000 \mathrm{~g}$ :

Sediment

Supernatant
Protein

(\% of total)

$100 \cdot 0$

$78 \cdot 0$

$23 \cdot 3$

$10 \cdot 6$

6.9

$51 \cdot 7$

$100 \cdot 0$

$15 \cdot 7$

$4 \cdot 7$

$5 \cdot 9$ $\begin{array}{cc}\text { RNA } & \begin{array}{c}\text { Phospholipid } \\ \text { (rel. concn.) }\end{array} \\ \mathbf{1 . 0 0} & 1.00\end{array}$

$\begin{array}{ll}0.35 & 0.58 \\ 1.45 & 1.70\end{array}$

Ratio RNA: Phospholipid: Protein

$\begin{array}{rlrlr}1.2 & : & 24.2 & : & 74.6 \\ 1.5 & : & 44.3 & : & 54.2 \\ & & & & \\ 7 \cdot 1 & : & 5.6 & : & 88.3 \\ 0.5 & : & 69.1 & : & 30.4\end{array}$


Table 2. Precipitation of radioactive lipoprotein from lipid-rich extract with ammonium sulphate

Lipid-rich extract was prepared as described in Table 1, Expt. 1, and $25 \mathrm{~g}$. of ammonium sulphate added/ $100 \mathrm{ml}$. of extract and the precipitate filtered off. Mitochondrial fraction had $35.9 \mu \mu \mathrm{c} / \mathrm{mg} ., 2.72 \mathrm{mg}$. of RNA/ $100 \mathrm{mg}$. of protein and $27.8 \mathrm{mg}$. of phospholipid/100 mg. of protein. Results are means from two experiments.

$\begin{array}{cccccc}\text { Fraction } & \overbrace{(\text { rel. concn. })}^{\text {Radioactivity in protein }} & \text { (\% of total) } & \begin{array}{c}\text { Protein } \\ \text { (\% of total) }\end{array} & \begin{array}{c}\text { RNA } \\ \text { (rel. concn.) }\end{array} & \begin{array}{c}\text { Phospholipid } \\ \text { (rel. concn.) }\end{array} \\ \text { rich extract } & 2.52 & 17.4 & 6.9 & 0.34 & 4.56 \\ \text { mium sulphate ppt. } & \mathbf{3 . 8 2} & \mathbf{1 3 . 7} & \mathbf{3 . 6} & \mathbf{0 . 6 2} & \mathbf{4 . 4 0}\end{array}$

Table 3. Application of method of Green et al. (1961b) for preparation of 'structural protein' to rat-liver mitochondria

Mitochondria had a final radioactivity of $63 \cdot 0 \mu \mu \mathrm{c} / \mathrm{mg}$. of protein.

\section{Treatment}

Total mitochondrial protein

(1) Proteins released into medium

(2) Disrupt mitochondria with detergent: $105000 \mathrm{~g}$ for $60 \mathrm{~min}$.

$$
\begin{aligned}
& \text { Sediment } \\
& \text { Supernatant }
\end{aligned}
$$

(3) Treat D with $12 \%$ satd. $\left(\mathrm{NH}_{4}\right)_{2} \mathrm{SO}_{4}$ : $3000 \mathrm{~g}$ for $15 \mathrm{~min}$.: Supernatant

(4) Wash sediment from (3) with 0.25 M-sucrose:

$$
\text { First washing }
$$$$
\text { Second washing }
$$

(5) Treat washed sediment from (4) with butan-1-ol: $3000 \mathrm{~g}$ for $15 \mathrm{~min}$.: Aq. phase

(6) Suspend floating protein layer from (5) in $0.25 \mathrm{M}$-sucrose: $3000 \mathrm{~g}$ for $15 \mathrm{~min}$.: Supernatant

(7) Treat sediment from (6) twice with $50 \%(\mathrm{v} / \mathrm{v})$ methanol at $50^{\circ}$ :

\begin{tabular}{|c|c|c|c|}
\hline \multirow[b]{2}{*}{ Fraction } & & \multirow{2}{*}{$\begin{array}{c}\text { Protein } \\
\text { (\% of total) }\end{array}$} \\
\hline & (rel. concn.) & (\% of total) & \\
\hline $\mathbf{A}$ & 1.00 & $100 \cdot 0$ & $100 \cdot 0$ \\
\hline B & $0 \cdot 11$ & $0 \cdot 6$ & $5 \cdot 8$ \\
\hline $\begin{array}{l}\text { C } \\
\text { D }\end{array}$ & $\begin{array}{l}3 \cdot 36 \\
0 \cdot 71\end{array}$ & $\begin{array}{l}34 \cdot 2 \\
46 \cdot 4\end{array}$ & $\begin{array}{l}10 \cdot 2 \\
65 \cdot 0\end{array}$ \\
\hline $\mathbf{E}$ & 0.49 & 23.9 & $48 \cdot 3$ \\
\hline $\begin{array}{l}\mathbf{F} \\
\mathbf{G}\end{array}$ & $\begin{array}{l}1.01 \\
1.08\end{array}$ & $\begin{array}{l}2 \cdot 9 \\
0 \cdot 8\end{array}$ & $\begin{array}{l}2.9 \\
0 \cdot 7\end{array}$ \\
\hline $\mathbf{H}$ & $0 \cdot 23$ & 0.5 & $2 \cdot 0$ \\
\hline I & $0 \cdot 0$ & 0.0 & 0.0 \\
\hline $\mathbf{J}$ & 1.25 & 22.9 & 18.2 \\
\hline
\end{tabular}

'Structural protein'
Radioactivity in protein

Table 4. Modification of method of Green et al. (1961 b) for preparation of 'structural protein' Mitochondria had a final radioactivity of $63 \cdot 0 \mu \mu \mathrm{C} / \mathrm{mg}$. of protein.

\section{Fraction}

Total mitochondrial protein

Protein released into medium

(1) First detergent extract Precipitation with $\left(\mathrm{NH}_{4}\right)_{2} \mathrm{SO}_{4}$ $0-5 \%$
$5-10 \%$
$10-15 \%$
$15-20 \%$
$20-25 \%$
Non-precipitated material

(2) Second detergent extract Precipitation with $\left(\mathrm{NH}_{4}\right)_{2} \mathrm{SO}_{4}$

\begin{tabular}{|c|c|c|}
\hline \multicolumn{2}{|c|}{ Radioactivity } & \multirow{2}{*}{$\begin{array}{c}\text { Protein } \\
\text { (\% of total) }\end{array}$} \\
\hline (rel. concn.) & (\% of total) & \\
\hline 1.00 & $100 \cdot 0$ & $100 \cdot 0$ \\
\hline 0.09 & $1 \cdot 3$ & $15 \cdot 0$ \\
\hline 0.0 & $0 \cdot 0$ & 0.0 \\
\hline 1.07 & $15 \cdot 2$ & $14 \cdot 2$ \\
\hline 1.07 & $4 \cdot 2$ & 3.9 \\
\hline $1 \cdot 12$ & $3 \cdot 2$ & 2.9 \\
\hline 0.91 & 1.5 & 1.7 \\
\hline 0.25 & 6.5 & $26 \cdot 6$ \\
\hline
\end{tabular}
$0-15 \%$
$15-20 \%$
$20-25 \%$
Non-precipitated material

(3) Residue insoluble in detergent
$0 \cdot 0$

$2 \cdot 69$

2.06

0.83

3.25

$\begin{array}{rr}0.0 & 0.0 \\ 1.1 & 0.4 \\ 0.6 & 0.3 \\ 1.0 & 1.2 \\ 28.9 & 8.8\end{array}$


contained $18 \%$ of the total mitochondrial protein and $23 \%$ of the total radioactivity. Since the various washings (fractions $\mathbf{F}-\mathbf{I}$ ) were less radioactive than the 'structural protein' it seemed probable that this protein was becoming labelled to a significant extent. However, the detergent mixture used did not extract all the mitochondrial protein, and a greenish brown residue was left (Table 3, fraction C) that contained $10 \%$ of the protein and $34 \%$ of the total radioactivity. In a modification of the method of Green and coworkers, this residual material was extracted with more detergent, and the ammonium sulphate was added in a stepwise manner (Table 4). A small amount of radioactive protein was extracted by the second detergent treatment, but the residue still contained nearly $30 \%$ of the total radioactivity. Since the ammonium sulphate fractionation did not yield any highly radioactive protein, and since the method now closely resembled that developed with Triton X100 (Tables 1 and 2) it was not modified further.

Subfractionation on calcium phosphate (Table 5). The lipid-rich extract was loaded on to a calcium phosphate column (see Methods section). The effluent during loading and washing with $0.02 \mathrm{M}$ buffer contained a small quantity of protein with a specific radioactivity 10-15 times that of the total mitochondrial protein (fraction C). Difficulties in analysing the small amount of material in the presence of a large excess of detergent have prevented an accurate chemical analysis of this fraction, but preliminary results indicate that it is poor in RNA but rich in phospholipid. The high radioactivity is not a consequence of the fact that detergent has been precipitated together with protein by trichloroacetic acid during the plating procedure, since mitochondrial protein precipitated with trichloroacetic acid had the same specific radioactivity if detergent was present or absent. Also, a very similar protein fraction isolated from the detergent-soluble proteins (see Table 6, fraction C) had a low specific radioactivity.

1.0M-Phosphate buffer eluted a yellowish brown turbid fraction. After clarification with Triton $X 100$, the eluted material showed a sharp peak at $410 \mathrm{~m} \mu$ and a broad absorption band between 515 and $600 \mathrm{~m} \mu$. After reduction with sodium dithionite, the peak at $410 \mathrm{~m} \mu$ shifted to $415 \mathrm{~m} \mu$ and two flat peaks appeared at 520 and $560 \mathrm{~m} \mu$. These results suggested the presence of haem proteins. The specific radioactivity of this fraction varied considerably between experiments, and it is not certain whether the radioactivity present was due to contamination with other fractions.

The material remaining attached to the column was three to four times as radioactive as the total mitochondrial protein. It showed a remarkable degree of binding and was not eluted with molar phosphate saturated with potassium chloride, or even by brief treatment with aq. $0.5 \%$ ammonia solution. For chemical analysis of the attached material the calcium phosphate was dissolved in $5 \%(w / v)$ trichloroacetic acid and the precipitated material analysed. Usually, however, the material was isolated by dissolving the column in sodium citrate (cf. Salk, 1941), centrifuging to obtain a floating layer of protein, dialysing this and

\section{Table 5. Subfractionation with calcium phosphate of lipid-rich component of the crude ribonucleic acid-lipoprotein complex}

Results are means from three experiments. Approx. $200 \mathrm{mg}$. of protein was fractionated. Mitochondria had a final radioactivity of $48.0 \mu \mu \mathrm{c} / \mathrm{mg}$. of protein and had $2.09 \mathrm{mg}$. of RNA and $26 \cdot 1 \mathrm{mg}$. of phospholipid/100 mg. of protein.

\section{Treatment}

Total mitochondrial protein

(1) Treat A with detergent and extract sediment with more detergent: Lipid-rich extract

(2) Load B on to calcium phosphate column:

Wash with 0.02 M buffer

Wash with $1.0 \mathrm{M}$ buffer

(3) Dissolve column in citrate: $15 \mathrm{~min}$. at $3000 \mathrm{~g}$ :

Floating layer

Aqueous layer

Sediment

(4) Dialyse $\mathrm{E}$ against 0.2 $\mathrm{m}$ buffer: $60 \mathrm{~min}$. at $105000 \mathrm{~g}$ :

Supernatant

Sediment

\begin{tabular}{|c|c|c|c|c|c|}
\hline \multirow[b]{2}{*}{ Fraction } & \multicolumn{2}{|c|}{ Radioactivity } & \multirow[b]{2}{*}{$\begin{array}{c}\text { Protein } \\
\text { (\% of } \\
\text { total) }\end{array}$} & \multirow[b]{2}{*}{$\begin{array}{c}\text { RNA } \\
\text { (rel. } \\
\text { concn.) }\end{array}$} & \multirow[b]{2}{*}{$\begin{array}{c}\text { Phospholipid } \\
\text { (rel. } \\
\text { concn.) }\end{array}$} \\
\hline & $\begin{array}{c}\text { (rel. } \\
\text { concn.) }\end{array}$ & $\begin{array}{l}\text { (\% of } \\
\text { total) }\end{array}$ & & & \\
\hline $\mathbf{A}$ & 1.00 & 100 & 100 & 1.00 & 1.00 \\
\hline B & $3 \cdot 05$ & $20 \cdot 6$ & $6 \cdot 8$ & $0 \cdot 83$ & $5 \cdot 55$ \\
\hline C & $11 \cdot 30$ & $5 \cdot 3$ & 0.5 & - & - \\
\hline $\mathrm{D}$ & $1 \cdot 50$ & $\mathbf{3} \cdot \mathbf{6}$ & $2 \cdot 0$ & 0.47 & 1.04 \\
\hline $\begin{array}{l}\mathrm{E} \\
\mathbf{F} \\
\mathrm{G}\end{array}$ & $\begin{array}{l}3 \cdot 44 \\
0 \cdot 0 \\
1 \cdot 70\end{array}$ & $\begin{array}{l}8 \cdot 1 \\
0 \cdot 0 \\
0 \cdot 4\end{array}$ & $\begin{array}{l}2 \cdot 4 \\
0 \cdot 5 \\
0 \cdot 2\end{array}$ & $\begin{array}{l}0.51 \\
0.55 \\
0.42\end{array}$ & $\begin{array}{l}2 \cdot 00 \\
2 \cdot 26 \\
5 \cdot 00\end{array}$ \\
\hline $\begin{array}{l}\text { H } \\
\text { I }\end{array}$ & $\begin{array}{l}0 \cdot 0 \\
3 \cdot 68\end{array}$ & $\begin{array}{l}0 \cdot 0 \\
9 \cdot 5\end{array}$ & $\begin{array}{l}0 \cdot 0 \\
2 \cdot 6\end{array}$ & $\overline{0 \cdot 32}$ & $\overline{2 \cdot 32}$ \\
\hline
\end{tabular}


sedimenting it at $105000 \mathrm{~g}$ (see Methods section). The material so obtained (Table 5, fraction I) is approximately four times as radioactive as the total mitochondrial protein and has the ratio of RNA: phospholipid :protein $0 \cdot 4: 38 \cdot 0: 61 \cdot 6$. The fractionation on calcium phosphate therefore shows that the crude lipoprotein in the lipid-rich component contains several different radioactive proteins and is clearly heterogeneous.

Presence of radioactive lipoproteins in detergentsoluble protein fractions. It had been observed previously during the chromatography of soluble mitochondrial proteins on calcium phosphate that elution with buffer of high molarity removed small quantities of relatively radioactive proteins (Roodyn et al. 1962, Table 4). Because of the properties of the lipid-rich component observed above, it was possible that similar proteins were present. The detergent-soluble protein fraction was therefore loaded on to calcium phosphate (Table 6) and submitted to the same procedure as that given in Table 5. Although the bulk of the protein was not retained by the column, some radioactive material remained attached after washing with molar buffer. It was found to be rich in phospholipid and poor in RNA (RNA : phospholipid : protein, $0 \cdot 2: 57 \cdot 2: 42 \cdot 6)$. When the column was dissolved in sodium citrate the attached lipoprotein behaved similarly to that obtained from the lipid-rich component described above. Treatment of the final sediment (Table 6, fraction $\mathrm{H}$ ) with butan-1-ol gave an insoluble protein, as with the lipid-rich component.

\section{DISCUSSION}

The disruption of the mitochondria with surfaceactive agents undoubtedly results from interaction of the detergent with the mitochondrial membrane.
It is not known whether the interaction is primarily with lipid, with non-polar side chains in the proteins making up the membrane (Green, Tisdale, Criddle \& Bock, 1961 $a$ ) or with both. The neutral detergents should not act by ionic interactions and hence should produce less denaturation of the protein than cationic or anionic detergents. Glassman (1950) observed that the inactivation and precipitation of botulinum-toxin protein produced by charged detergents did not occur with the neutral detergent Triton A 20. Neutral detergents have been used by several workers to study the release of enzymes from subcellular particles (e.g., Walker \& Levvy, 1953; Feinstein, 1959; Bendall \& de Duve, 1960) without any reports of enzyme inactivation. Use of Triton X100 for extraction did not inactivate malic dehydrogenase and it was possible afterwards to obtain 100-fold purification of the enzyme (Roodyn et al. 1962). The fact that the protein could be readily adsorbed on to calcium phosphate columns from detergent solutions without prior removal of the detergent indicated that strong electrovalent links between protein and detergent were lacking. The interaction with detergent is determined not only by the absolute concentration of detergent (Figs. 1, 5 and 6) but also by the ratio of detergent to mitochondrial protein (Fig. 2). This is a general phenomenon of interaction between detergents and proteins (Putnam, 1948). The effect of chain length of detergent (Fig. 4) would also suggest that the mitochondrial lysis not only depends on the absolute concentration of detergent but requires some interaction between detergent and mitochondria. In the activation of latent adenosine triphosphatase of rat-liver mitochondria by saturated fatty acids, Pressman \& Lardy (1956) observed that a chain length of 14 was optimum. Thus it seems likely that steric factors are involved

Table 6. Presence of radioactive protein fraction in detergent-soluble proteins

Results are means from two experiments. Mitochondrial protein had a final radioactivity of $48 \cdot 3 \mu \mu \mathrm{c} / \mathrm{mg}$. Mitochondria containing $182 \mathrm{mg}$. of protein were fractionated. Fraction $\mathrm{H}$ contained $1.3 \mathrm{mg}$. of protein.

\begin{tabular}{|c|c|c|}
\hline Treatment & Fraction & $\begin{array}{l}\text { Radioactivity } \\
\text { (rel. concn.) }\end{array}$ \\
\hline al mitochondrial protein & A & 1.00 \\
\hline $\begin{array}{l}\text { Treat A with detergent: } 60 \mathrm{~min} \text {. at } 105000 \mathrm{~g} \text { : } \\
\text { Supernatant }\end{array}$ & B & $0 \cdot 42$ \\
\hline $\begin{array}{l}\text { Load B on to calcium phosphate column: } \\
\text { Wash with } 0.02 \mathrm{M} \text { buffer } \\
\text { Wash with } 1.0 \mathrm{M} \text { buffer }\end{array}$ & $\begin{array}{l}\mathrm{C} \\
\mathrm{D}\end{array}$ & $\begin{array}{l}0.37 \\
0.39\end{array}$ \\
\hline $\begin{array}{l}\text { Dissolve column in citrate: } 3000 \mathrm{~g} \text { for } 15 \mathrm{~min} . \mathrm{:} \\
\text { Floating layer } \\
\text { Aqueous phase }\end{array}$ & $\begin{array}{l}\mathbf{E} \\
\mathbf{F}\end{array}$ & $\begin{array}{l}0.99 \\
0.88\end{array}$ \\
\hline $\begin{array}{l}\text { Dialyse E against } 0.02 \mathrm{M} \text { buffer: } 60 \mathrm{~min} . \text { at } \\
105000 \mathrm{~g} \text { : } \\
\text { Supernatant } \\
\text { Sediment }\end{array}$ & $\begin{array}{l}\mathrm{G} \\
\mathrm{H}\end{array}$ & $\begin{array}{l}0 \cdot 0 \\
1 \cdot 42\end{array}$ \\
\hline
\end{tabular}


in reactions of surface-active materials with the mitochondrial membrane.

The sequence of events as the mitochondria are exposed to increasing concentrations of detergent may now be described. The first clear effect is the release of soluble mitochondrial protein. It is probably an over-simplification to imagine that the mitochondrion simply 'bursts' on addition of detergent. Watson \& Siekevitz (1956) exposed ratliver mitochondria to increasing concentrations of sodium deoxycholate. The mitochondria first swelled considerably and the inner membrane and christae mitochondriales appeared at one side of the outer membrane. The particles then shrank and the matrix cleared considerably. Both the inner and outer membranes then became progressively less electron-dense until the preparation finally consisted of empty vesicles. At no stage was there sudden disruption of the mitochondrial membrane, but rather there seemed to be a steady extraction of material from it. This accords well with the above-mentioned observations. If the mitochondria merely burst when the detergent had reached a critical concentration, one would expect a sudden release of soluble protein, leaving residual material of constant composition. However, the release of protein is spread out over a fairly wide range of detergent concentration (Fig. 6), and the composition of the insoluble fragments is found to vary as the detergent concentation is raised (Figs. 5 and 7). In addition, the detergent-soluble fraction contains a radioactive lipoprotein very similar in properties to material that can be extracted from the membrane or 'insoluble' component (Table 6). This suggests that a range of particles, from free proteins down to large lipoprotein aggregates, is liberated by the detergent. The definition of 'soluble' is clearly operational and is often used synonymously with 'material not sedimenting after $60 \mathrm{~min}$. at $100000 \mathrm{~g}$.

Having lost its main easily soluble component the mitochondrion is now relatively rich in RNA, phospholipid and succinoxidase and appears as a reddish brown translucent pellet. This has been described above as the 'RNA-lipoprotein complex', although it should be stressed that the amount of RNA is small compared with the amount of lipid. Other workers have obtained similar fractions from liver mitochondria, disrupted by a variety of methods. For example, Hogeboom \& Schneider (1950) disrupted mitochondria by rather prolonged treatment with sonic vibrations and found that the material sedimenting after $148000 \mathrm{~g}$ for $30 \mathrm{~min}$. contained succinoxidase and cytochrome oxidase. By using shorter treatment with sound waves, McMurray, Maley \& Lardy (1958) obtained a similar fraction consisting of vesicles $0.05-0.5 \mu$ in diameter capable of carrying out oxidative phos- phorylation. Cooper \& Lehninger (1956) used digitonin to prepare a sub-particle also capable of oxidative phosphorylation. This material was rich in bound respiratory enzymes (Devlin, 1959) and appears under the electron microscope as aggregates of small vesicles 200-500 $\AA$ in diameter (Siekevitz \& Watson, 1957). Harel, Jacob \& Moulé (1957) obtained a fraction rich in RNA, phospholipid and succinoxidase from mitochondria disrupted by freezing and thawing. Particles capable of oxidizing NADH have been obtained by grinding mitochondria with alumina and centrifuging the disrupted mitochondria for $60 \mathrm{~min}$. at $100000 \mathrm{~g}$ (Baltscheffsky, Fudge \& Arwidsson, 1960). Siekevitz \& Watson (1956) used sodium deoxycholate and observed that the material sedimenting after $60 \mathrm{~min}$. at $105000 \mathrm{~g}$ was rich in succinoxidase, phospholipid and RNA. By correlation with electron microscopy (Watson \& Siekevitz, 1956) it was clear that this fraction was essentially derived from the mitochondrial membrane. Since these workers ascribed the presence of RNA in this fraction to contaminant microsomal material, it cannot be certain that the RNA in the RNAlipoprotein complex is derived from the mitochondrial membrane (see below, however).

Further extraction with detergent removes material in which the ratio of phospholipid to protein is high $(1.5$ or $2: 1)$ and which contains very little RNA (Tables 1 and 2). The extraction of phospholipid proceeds in parallel with the inactivation of succinoxidase (see also Nygaard, 1953). The extracted material probably contains several different proteins, including haem proteins, as revealed by fractionation with calcium phosphate. However, if the crude extract is precipitated with ammonium sulphate and treated with butan-1-ol, an insoluble protein is obtained that is very similar to the 'structural protein' of ox-heart mitochondria described by Green et al. (1961b). The application of the method of Green et al. $(1961 b)$ for the preparation of structural protein from rat-liver mitochondria was not entirely successful because of incomplete extraction of the mitochondria (Tables 3 and 4), but the results were consistent with the presence of a protein similar to that obtained from ox heart and with it becoming labelled to a significant extent in vitro. It is reasonable to suppose therefore that the more prolonged detergent treatment removes normally insoluble lipoprotein, the protein portion of which has the properties of an insoluble structural protein after treatment with butan-1-ol. The extracted lipoprotein fraction has the highest rate of labelling in vitro of all the mitochondrial subfractions studied.

The experiments reported above have provided some more information about the properties of the small amount of RNA found in the mitochondrial 
fraction. Since repeated washing of mitochondria failed to remove all the RNA but did remove added microsomes, and since the incorporation process differed in several major respects from the microsomal system (e.g. lack of requirement for cell sap) it seems reasonable to infer from previous experiments (Roodyn et al. 1961 $a$ ) that the RNA present in the mitochondrial fraction is not simply due to microsomal contamination.

The bulk of the RNA in the mitochondrial fraction is resistant to extraction by detergent (Fig. 7) and the residue after prolonged extraction is relatively rich in RNA (containing $7-10 \%$ of RNA) and poor in phospholipid (Table 1). It is not known if the residual mitochondrial RNA is present as ribosomes. Certainly no material in which the RNA:protein ratio approaches unity has been isolated from mitochondria. In this connexion, a ribonuclease-resistant incorporation system, with properties similar to the mitochondrial system, has been isolated from the light microsomal fraction (Prosser, Hird \& Munro, 1961). Similar fractions, rich in 'smooth membranes', contain significant amounts of RNA (Moulé, Rouiller \& Chauveau, 1960; Chauveau, Moulé, Rouiller \& Schneebeli, 1962). The existence of RNA in the mitochondrial membrane, with a role in protein synthesis, is therefore feasible (cf. Hendler, 1962). However, it is clear that more work is required on the properties of mitochondrial RNA before this possibility can be established with certainty.

The results of the above-described fractionation studies may now be considered in relation to mitochondrial-protein synthesis. The most striking conclusion is that incubation in vitro results in labelling of insoluble lipoprotein probably derived from the mitochondrial membrane. There is some labelling of protein bound to RNA but it is less than that of the lipoprotein. The rate of labelling of the truly soluble proteins (e.g. malic dehydrogenase and cytochrome $c$ ) is negligible (Roodyn et al. 1962). However, there is some evidence that the pattern of labelling in vivo is very different. Marsh \& Drabkin (1957) observed good labelling of cytochrome $c$ in vivo. Fletcher \& Sanadi (1961) showed that the turnover rates in vivo of cytochrome $c$, soluble protein, residual protein and lipid of ratliver mitochondria were identical, and, in confirmation of this, Dr K. B. Freeman in our Laboratory has recently observed that the rate of labelling in vivo of mitochondrial subfractions prepared by the methods in this paper are not strikingly different. Such results suggest that the various components of the mitochondria are assembled simultaneously in the living cell.

To bring these observations together, it could be imagined that the assembly of the mitochondrion proceeds by a reversal of the events observed during its degradation. It has been shown above that the main stages of the disruption by detergent are most probably those in Scheme 1.

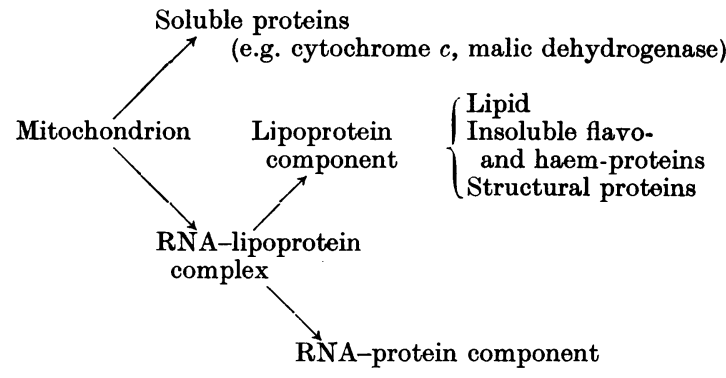

Scheme 1

Reversal of the process in Scheme 1 might occur as follows. The primary template is a RNAprotein fraction (possibly derived from the nucleus; Roodyn, Reis \& Work, $1961 b$ ). On this are synthesized the structural proteins, which have specific binding sites for lipid and certain haemproteins, as described by Criddle, Bock, Green \& Tisdale (1961). The result is the formation of a RNA-lipoprotein complex, containing attached respiratory enzymes arranged in their correct relative positions, and possibly corresponding to the mitochondrial 'monomer' or mitochondrial sub-unit described by Green (1959). The sub-units then polymerize to form the mitochondrial membrane, thus enclosing the soluble mitochondrial proteins. The soluble proteins and the bound respiratory enzymes of the membrane are synthesized on the ribosomes, in a region of the endoplasmic reticulum close to the site of assembly of the mitochondria. The mitochondrial RNA controls only the synthesis of the insoluble structural proteins of the membrane. In vivo, therefore, simultaneous labelling of all components could occur. Incubation of mitochondria in vitro, however, would result only in labelling of the insoluble structural material. Such a view should be regarded only as a preliminary working hypothesis, however, since the synthesis of a well-characterized structural protein of high purity has not yet been demonstrated in this work.

\section{SUMMARY}

1. Rat-liver mitochondria were incubated in vitro with radioactive valine and the distribution of radioactive protein was determined in mitochondrial subfractions obtained after disruption with detergent.

2. The extent of disruption by Triton detergents was affected by the chain length of the detergent, 
the detergent concentration, the mitochondrial concentration and the time of exposure of the mitochondria to detergent.

3. By variation of these factors it was possible to obtain controlled disruption and to extract the various components of mitochondria in a sequential fashion.

4. By differential centrifuging of the disrupted mitochondria, a fraction rich in respiratory enzymes, ribonucleic acid and phospholipid, and containing the bulk of the radioactive protein, was obtained. The fraction was probably derived from the mitochondrial membrane.

5. Treatment of this fraction with more detergent separated it into a ribonucleic acid-rich component and a lipid-rich component, the latter having protein of higher specific radioactivity.

6. Treatment of the crude lipoprotein in the lipid-rich component with butan-1-ol gave a protein similar in properties to the 'structural protein' of ox-heart mitochondria described by other workers.

7. Fractionation of the lipid-rich component on calcium phosphate revealed the presence of at least two radioactive proteins.

8. It is concluded that the major site of incorporation of amino acids, in vitro, is into insoluble lipoprotein, probably derived from the mitochondrial membrane.

9. An hypothesis to explain the pattern of labelling observed in vitro is presented.

The author is grateful to Miss J. S. Coomber and Miss A. M. Pearson for technical assistance and to Dr T. S. Work for his kind interest and guidance in this work.

\section{REFERENCES}

Baltscheffsky, H., Fudge, M. \& Arwidsson, B. (1960). Acta chem. scand. 14, 247.

Bendall, D. S. \& de Duve, C. (1960). Biochem. J. 74, 444.

Chauveau, J., Moulé, Y., Rouiller, C. \& Schneebeli, J. (1962). J. Cell Biol. 12, 17.

Cooper, C. \& Lehninger, A. L. (1956). J. biol. Chem. 219, 489.
Criddle, R. S., Bock, R. M., Green, D. E. \& Tisdale, H. D. (1961). Biochem. biophys. Res. Commun. 5, 75.

Devlin. T. M. (1959). J. biol. Chem. 234, 962.

Feinstein, R. N. (1959). Arch. Biochem. Biophys. 79, 399.

Fletcher, M. J. \& Sanadi, D. R. (1961). Biochim. biophys. Acta, 51, 356.

Glassman, H. N. (1950). Ann. N.Y. Acad. Sci. 53, 91.

Green, D. E. (1959). Advanc. Enzymol. 21, 73.

Green, D. E., Tisdale, H. D., Criddle, R. S. \& Bock, R. M. $(1961$ a). Biochem. biophys. Res. Commun. 5, 81.

Green, D. E., Tisdale, H. D., Criddle, R. S., Chen, P. Y. \& Bock, R. M. (1961 b). Biochem. biophys. Res. Commun. 5, 109.

Harel, L., Jacob, A. \& Moulé, Y. (1957). Bull. Soc. Chim. biol., Paris, 39, 819.

Hendler, R. W. (1962). Nature, Lond., 193, 821.

Hogeboom, G. H. \& Schneider, W. C. (1950). Nature, Lond., 166, 302.

McMurray, W. C., Maley, G. F. \& Lardy, H. A. (1958). J. biol. Chem. 230, 219.

Marsh, J. B. \& Drabkin, D. L. (1957). J. biol. Chem. 224, 909.

Moulé, Y., Rouiller, C. \& Chauveau, J. (1960). J. biophys. biochem. Cytol. 7, 547.

Nygaard, A. P. (1953). J. biol. Chem. 204, 655.

Pressman, B. C. \& Lardy, H. A. (1956). Biochim. biophys. Acta, 21, 458 .

Prosser, E. J. T., Hird, H. J. \& Munro, H. N. (1961). Biochem. biophys. Res. Commun. 4, 243.

Putnam, F. W. (1948). Advanc. Protein Chem. 4, 79.

Reis, P. J., Coote, J. L. \& Work, T. S. (1959). Nature, Lond., 184, 165.

Roodyn, D. B. (1961). Progr. Biophys.biophys. Chem.11, 254.

Roodyn, D. B., Reis, P. J. \& Work, T. S. (1961 a). Biochem. J. 80, 9.

Roodyn, D. B., Reis, P. J. \& Work, T. S. (1961b). In Protein Biosynthesis, p. 37. Ed. by Harris, R. J. C. London: Academic Press Inc.

Roodyn, D. B., Suttie, J. W. \& Work, T. S. (1962). Biochem. J. 83, 29.

Salk, J. E. (1941). Proc. Soc. exp. Biol., N.Y., 46, 709.

Schneider, W. C. \& Potter, V. R. (1943). J. biol. Chem. 149, 217.

Siekevitz, P. \& Watson, M. L. (1956). J. biophys. biochem. • Cytol. 2, 653.

Siekevitz, P. \& Watson, M. L. (1957). Biochim. biophys. Acta, 25, 274.

Walker, P. G. \& Levvy, G. A. (1953). Biochem. J. 54, 56.

Watson, M. L. \& Siekevitz, P. (1956). J. biophys. biochem. Cytol. 2, 639 . 